\title{
Analisis Firm Value dengan Pemoderasi Corporate Social Responsibility
}

\author{
Pancawati Hardiningsih*, Sartika Wulandari, Ceacilia Srimindarti \\ dan Rachmawati Meita Oktaviani \\ Fakultas Ekonomi dan Bisnis Universitas STIKUBANK \\ *Email : pancawati@edu.unisbank.ac.id
}

\begin{abstract}
Increasing firm value is a good perception of the company. Maintaining a good reputation can facilitate the addition of capital and increase sales due to public trust. The company's reputation can be maintained through corporate social responsibility (CSR) programs. This study examines the effect of solvency (DER) and company profitability (ROA) on the value of the company with CSR as a moderator. The population of this research is garment and textile companies listed on the Indonesia Stock Exchange in 2015-2017. The research sample used purposive sampling technique, so that it was obtained by 57 observations. The data analysis technique uses a multiple linear regression model of moderation with the based on interaction. Hypothesis test results show that ROA and CSR have a significant positive effect on firm value. While the DER variable does not affect the value of the company. CSR is proven to strengthen ROA towards company value.
\end{abstract}

Keywords: Corporate Value, CSR, Profitability, Solvability.

\section{PENDAHULUAN}

Reputasi perusahaan dapat dijaga melalui program corporate social responsibility (CSR) seperti program beasiswa, pelatihan olahraga, program kesehatan, membangun jembatan, pelestarian lingkungan, pemeliharaan fasilitas umum, pengadaan air bersih, dan lain-lain. Kegiatan bakti perusahaan terhadap masyarakat atau CSR award memberikan penghargaan kepada perusahaan dengan program terbaiknya untuk masyarakat. Bentuk dan cara perusahaan berbeda dalam menyalurkan program CSR nya, semakin besar dana yang dicurahkan untuk kegiatan sosial semakin panjang program dan semakin dikenal pula nama perusahaan. Sementara apresiasi dan nada negative tidak lepas dari tanggapan public terhadap CSR yang dilaksanakan perusahaan, program peduli sekitar atau memang hanya sebagai marketing terselubung.

Nilai perusahaan merupakan suatu tolak ukur capaian prestasi kerja. Jika seorang manajer mampu untuk meningkatkan nilai perusahaan maka kemakmuran pemegang saham juga meningkat. Sedangkan bagi investor peningkatan nilai perusahaan merupakan persepsi yang baik terhadap perusahaan. Hal ini akan menarik minat investor lain dalam berinvestasi sehingga harga saham akan terefleksi dengan demikian nilai perusahaan pun akan meningkat. Kondisi didukung pendapat Wardani dan Hermuningsih (2009) bahwa nilai perusahaan merupakan persepsi investor terhadap perusahaan, yang sering dikaitkan dengan harga saham. Demikian juga Pujiati dan Widanar (2009) juga menyatakan bahwa harga pasar saham perusahaan merupakan suatu cerminan penilaian investor secara keseluruhan atas setiap ekuitas yang dimiliki. Selain itu, harga pasar saham menunjukkan penilaian sentral diseluruh pelaku pasar, dan bertindak sebagai barometer kinerja manajemen perusahaan.

Penilaian prestasi perusahaan dapat dilihat dari kemampuan perusahaan dalam menghasilkan laba. Laba merupakan indicator kemampuan perusahaan memenuhi kewajiban investor juga merupakan elemen penciptaan nilai prospek perusahaan di masa yang akan datang. Kinerja keuangan yang baik akan meningkatkan nilai perusahaan melalui pengelolaan aset dan modal yang dimiliki. ROE juga merupakan suatu basic test seberapa efektif manajemen perusahaan menggunakan uang investor dibandingkan dengan ROA yang hanya mengukur keefisienan suatu perusahaan dalam menghasilkan return atas asetnya (Mc Clure,2009). Sri Rahayu (2010); Sambora dkk (2014) menemukan ROE tidak berpengaruh signifikan terhadap nilai, Namun berbeda dengan Yuniasih dan Wirakusuma (2007) menunjukkan bahwa ROA berpengaruh positif terhadap nilai perusahaan. Hal ini sejalan dengan Hartoyo (2009); Khumairoh dkk (2015); Pratama dan Wiksuana 
(2016); Nurminda dkk (2017); Pristianingrum (2017); dan Ramadhani, dkk (2018) bahwa ROE berpengaruh positif signifikan terhadap nilai perusahaan. Demikian juga Dwijayanti, dkk. (2011); Pratama dan Wiksuana (2016) menunjukkan bahwa ROA dan EVA berpengaruh positif dan signifikan terhadap return saham untuk periode ke depan. Oleh karena itu, ROA merupakan salah satu faktor yang berpengaruh terhadap nilai perusahaan. Sedangkan Carningsih (2012) menemukan bahwa ROA berpengaruh negative terhadap nilai perusahaan.

Pendanaan merupakan salah satu fungsi perusahaan yang penting bagi keberlangsungan usaha suatu perusahaan Kebutuhan pendanaan dapat dipenuhi dari internal perusahaan maupun eksternal perusahaan. Pasar modal merupakan salah satu alternative sumber pendanaan yang memberikan kesempatan investasi bagi investor perorangan maupun institusional. Investasi dalam bentuk saham dapat memberikan keuntungannya melebihi bunga deposito dan obligasi, meskipun hukum high risk high return tetap berlaku. Terlebih, pada 2015 modal yang dibutuhkan untuk berinvestasi saham dipermudah dengan menurunkan minimum pembelian lembar saham dari semula lima ratus menjadi seratus lembar saja. Kinerja keuangan yang baik akan meningkatkan nilai perusahaan jika pengelolaan pendanaan melalui hutang atau emisi saham dilakukan secara efektif.

Penelitian tentang kebijakan hutang dilakukan oleh Bambang (2009); Ogolmagai (2013); dan Sambora dkk (2014) menyimpulkan bahwa leverage tidak berpengaruh terhadap nilai perusahaan. Sementara Guspitasari (2013); Pratama dan Wiksuana (2016); dan Ramadhani, dkk (2018) menyimpulkan leverage berpengaruh positif signifikan terhadap nilai perusahaan. Sedangkan berbeda dengan riset Guspitasari (2013); Khumairoh dkk (2015); Khafa (2015); dan Linawaty dan Ekadjaja (2017) menemukan leverage berpengaruh negatif terhadap nilai perusahaan.

Perusahaan dalam perkembangannya akan selalu berusaha untuk mempertahankan keunggulan bisnisnya dalam meningkatkan nilai perusahaan. Kepedulian dunia usaha untuk menyisihkan dana aktifitas CSR secara berkelanjutan akan mendatangkan sejumlah manfaat bagi dunia bisnis dan stakeholder. CSR dipercaya dapat meningkatkan nilai perusahaan, dimana para investor cenderung menanamkan modalnya kepada perusahaan yang memiliki kepedulian sosial, dengan menggunakan informasi tanggung jawab sosial sebagai salah satu keunggulan perusahaannya. Penelitian tentang CSR yang menghubungkan kinerja keuangan dengan nilai perusahaan masih beragam. Rustiarini (2010); Khafa (2015); dan Murnita dan Putra (2017) menemukan bahwa pengungkapan CSR berpengaruh positif terhadap nilai perusahaan. Hasil berbeda ditemukan oleh Pristianingrum (2017) bahwa pengungkapan CSR tidak berpengaruh terhadap nilai perusahaan. Pengungkapan CSR terbukti memperkuat pengaruh ROA terhadap nilai perusahaan yang berarti selain melihat kinerja keuangan, pasar juga memberikan respons terhadap pengungkapan CSR yang dilakukan perusahaan. Kondisi tersebut didukung oleh hasil penelitian Yuniasih dan Wirakusuma (2007); Oktavias (2015); dan I Ketut (2016).

Ukuran perusahaan dianggap mampu untuk mempengaruhi nilai perusahaan (Martini dkk, 2014). Semakin besar skala perusahaan maka perusahaan semakin dipercaya oleh kreditur dalam memperoleh sumber dana yang besar baik bersifat internal maupun eksternal. Sumber dana tersebut dapat digunakan oleh perusahaan untuk lebih meningkatkan keuntungan perusahaan melalui ekspansi dan effisiensi (Maspupah, 2014). Semakin besar ukuran perusahaan, maka ada kecenderungan lebih banyak investor yang menaruh perhatian pada perusahaan tersebut. Hal ini disebabkan karena perusahaan yang besar cenderung memiliki kondisi yang lebih stabil dari tahun ke tahun utamanya dalam return saham. Peningkatan permintaan akan saham suatu perusahaan menjadi penyebab atas naiknya harga saham perusahaan di pasar modal yang berujung pada kenaikan nilai perusahaan (Zumrotun, 2013). Beberapa penelitian tentang size dilakukan oleh Eka (2010); Chen Li dan Chen Shun (2011); Martini dkk (2014); Maspupah (2014); Khumairoh dkk (2015); I Gustu dan I Ketut (2016); dan Pramana (2016) menemukan bahwa ukuran perusahaan berpengaruh positif dan signifikan terhadap nilai perusahaan. Penelitian ini bertujuan untuk menganalisis pengaruh return on asset, debt to equity ratio, CSR, dan peran moderasi ROA terhadap nilai perusahaan?

Isyarat atau signal adalah suatu tindakan yang diambil perusahaan untuk memberi petunjuk bagi investor tentang bagaimana manajemen memandang prospek perusahaan Brigham dan Houston (2001). Sinyal ini berupa informasi mengenai apa yang sudah dilakukan oleh manajemen untuk merealisasikan keinginan pemilik. Sinyal dapat berupa informasi yang menyatakan bahwa 
perusahaan tersebut lebih baik daripada perusahaan lain (Sari dan Zuhrotun,2006). Informasi yang dikeluarkan oleh perusahaan merupakan hal yang penting, karena hakekatnya menyajikan keterangan, catatan atau gambaran, baik untuk keadaan masa lalu, saat ini maupun masa yang akan datang bagi kelangsungan hidup perusahaan dan bagaimana efeknya pada perusahaan. Integritas informasi laporan keuangan yang mencerminkan nilai perusahaan merupakan sinyal positif yang dapat mempengaruhi opini investor dan kreditor atau pihak-pihak lain yang berkepentingan. Laporan keuangan seharusnya memberikan informasi yang berguna bagi investor dan kreditor untuk membuat keputusan investasi, kredit dan keputusan sejenis. Pengeluaran investasi memberikan sinyal positif tentang pertumbuhan perusahaan dimasa yang akan datang, sehingga meningkatkan harga saham sebagai indikator nilai perusahaan (Hasnawati,2005).

\section{METODE PENELITIAN}

Populasi dalam penelitian ini adalah perusahaan manufaktur yang listed di BEI. Sampel terpilih adalah perusahaan garment dan tekstil yang terdaftar di BEI pada tahun 2015-2017. Teknik purposive sampling digunakan dalam penelitian ini dengan asusmsi perusahaan yang memiliki kelengkapan data pada variable yang dibutuhkan, sehingga diperoleh sampel sebanyak 19 perusahaan dengan 57 observasi.Data yang digunakan dalam penelitian ini adalah data sekunder dari laporan keuangan yang dipublikasi dalam annual report. Sumber data laporan keuangan tersebut diperoleh dari website www.idx.co.id melalui pengumuman dan kinerja keuangan dari perusahaan bidang tekstil dan garment yang terdaftar pada rentang waktu 2015-2017.

Model regresi linear berganda model moderasi dengan basis interaksi. Adapun model persamaan model penelitian sebagai berikut:

$$
\mathrm{NP}=\alpha+\beta 1 \mathrm{ROA}+\beta 2 \mathrm{DER}+\beta 3 \mathrm{CSR}+\beta 4 \mathrm{ROA} * \mathrm{CSR}+\beta 5 \mathrm{Size}+\mathrm{e}
$$

\section{HASIL DAN PEMBAHASAN}

\section{Statistik Deskriptif}

Statistik deskriptif dalam penelitian ini dapat dilihat sebagai berikut :

Tabel 1. Statistik Deskriptif

\begin{tabular}{|l|r|r|r|r|r|}
\hline & \multicolumn{1}{|c|}{$\mathrm{N}$} & \multicolumn{1}{c|}{ Minimum } & \multicolumn{1}{c|}{ Maximum } & \multicolumn{1}{c|}{ Mean } & \multicolumn{1}{c|}{ Std. Deviation } \\
\hline ROA & 57 & -2.07 & 12.12 & 7.5958 & 7.16770 \\
DER & 57 & -30.60 & 27.98 & 1.3941 & 7.52938 \\
CSR & 57 & 9.00 & 55.00 & 33.0392 & 13.34310 \\
PBV & 57 & -9.03 & 2.74 & .4939 & 1.67926 \\
SIZE & 57 & 27.5800 & 33.4100 & 31.257959 & 1.5535403 \\
& & & & & \\
Valid N (listwise) & 57 & & & & \\
\hline
\end{tabular}

Sumber: Data diolah, 2018

Hasil pengujian Tabel 1 mean ROA mempunyai nilai sebesar 7.5958 dan standar deviasi sebesar 7.16770. CSR mempunyai nilai mean sebesar 33.0392 dan standar deviasi sebesar 13.34310. DER mempunyai nilai mean sebesar 1.3941 dan standar deviasi sebesar 7.52938. PBV mempunyai nilai mean sebesar .4939 dan standar deviasi sebesar 1.67926. Sedangkan Size mempunyai nilai mean sebesar 31.257959 dan standar deviasi sebesar 1.5535403 .

\section{Uji Normalitas}

Hasil uji normalitas dilakukan dengan menggunakan nilai Zskew dan Zkurt dengan membandingkan nilai kritisnya sebagai berikut:

$$
\begin{gathered}
\text { Z skew }=-0,180 \\
\sqrt{ } 6 / 30 \\
=-0.664
\end{gathered}
$$

$$
\begin{aligned}
\text { Zkurt } & =\frac{0,427}{\sqrt{24 / 30}} \\
& =0.798
\end{aligned}
$$


Hasil perhitungan menunjukkan nilai Zskweness sebesar -0.664 sedangkan nilai Zkurtosis 0.798 , dengan nilai kritisnya $\pm 1,96$. Jadi dapat disimpulkan bahwa data penelitian tersebut memiliki distribusi secara normal.

\section{Uji Asumsi Klasik}

\section{Uji Multikolinieritas}

Uji multikolinieritas dapat dilihat dari nilai Tolerance dan Variance Inflation diketahui bahwa nilai Tolerance untuk variabel independent ROA sebesar 0, 946, DER sebesar 0, 938, CSR 0, 958, dan Size sebesar 0,845 mempunyai angka yang lebih besar dari 0,1. Sedangkan nilai VIF pada variabel ROA sebesar 1.057, variabel DER sebesar 1.067, variabel CSR sebesar 1.044 dan Size sebesar 1,232 yang berarti mempunyai nilai VIF $\leq 10$, sehingga dapat disimpulkan bahwa tidak terjadi multikolinieritas antar variabel bebas.

\section{Uji Autokorelasi}

Uji autokorelasi dengan pengujian Durbin-Watson (uji D-W) diperoleh nilai Durbin-Watson sebesar 2,175. Jika dibandingkan dengan jumlah observasi sebanyak 57 dan jumlah variabel independen $3(\mathrm{k}=3)$, maka nilai $\mathrm{du}=1,4273$ dan nilai $\mathrm{dl}=1.6754$. Oleh karena nilai DW 2.175 lebih kecil dari batas atas (du) 1,4273 dan kurang dari, 4- 1.6754 (4-du) diperoleh 2.324, sehingga nilai 2,175 diantara (du) dan (4-du) maka dinyatakan tidak ada autokorelasi.

\section{Uji Heteroskedastisitas}

Uji Heteroskedastisitas dilakukan dengan uji glejser. Uji glejser ini mengusulkan untuk meregres nilai absolute residual terhadap variabel independen dengan persamaan regresi: $|\mathbf{U t}|=\boldsymbol{\alpha}+$ $\beta X t+v t$.

Hasil uji glejser terlihat bahwa nilai koefisien parameter sig. untuk variabel ROA adalah sebesar 0,141, variabel DER sebesar 0,448, variabel CSR 0,780, dan variabel Size sebesar 0,424. Nilai signifikan semua variable menunjukkan $\mathrm{p}>0,05$ maka disimpulkan tidak terjadi gelaja heteroskedastisitas pada model penelitian tersebut.

\section{Analisis Regresi Berganda}

Hasil analisis regresi berganda berupa koefisien untuk masing-masing variabel independen. Koefisien ini diperoleh dengan cara memprediksi nilai variabel dependen dengan suatu persamaan. Hasil analisis regresi linear berganda yang digunakan untuk mengalisis variabel dalam penelitian ini sebagai berikut.

Tabel 2. Regresi Linear Berganda Sebelum Dikontrol

\begin{tabular}{lcccl}
\hline Variabel & $\begin{array}{c}\text { Beta } \\
\text { Unstandardized } \\
\text { Coefficients }\end{array}$ & t & Sig & Keterangan \\
\hline (Constant) &, 723 & 2,541 &, 033 & \\
\hline DER & .084 &, 572 &, 543 & $\begin{array}{l}\text { H2 } \\
\text { terdukung }\end{array}$ \\
\hline ROA &, 417 & 3,176 &, 002 & H1 terdukung \\
\hline CSR &, 372 & 2,542 &, 026 & H3 terdukung \\
\hline CSR*ROA & & & & H4 terdukung \\
\hline Adjusted R ${ }^{2}$ & 0,463 & & & \\
F Test & 0,002 & & & \\
\hline Sumber: Data diolah, 2018 & & &
\end{tabular}

Tabel 2 menunjukkan hasil regresi sebelum dimasukkan variabel kontrol sedangkan tabel 3 menunjukkan hasil regresi setelah dimasukkan variabel kontrol. Kondisi ini menunjukkan model penelitian menjadi lebih baik karena nilai adjusted $\mathrm{R}^{2}$ sebelum dikontrol sebesar 46,3\% menjadi lebih tinggi setelah dikontrol yaitu sebesar 55,4\%. 
Tabel 3. Regresi Linear Berganda Setelah Dikontrol

\begin{tabular}{lcccl|}
\hline Variabel & $\begin{array}{c}\text { Beta } \\
\text { Unstandardized } \\
\text { Coefficients }\end{array}$ & t & Sig & Keterangan \\
\hline (Constant) & $-1,667$ & 2,561 &, 023 & \\
\hline DER &, 071 & .427 &, 650 & $\begin{array}{l}\text { H2 } \\
\text { terdukung }\end{array}$ \\
\hline ROA &, 299 & 3,007 &, 006 & H1 terdukung \\
\hline CSR &, 383 & 2,841 &, 023 & H3 terdukung \\
\hline CSR*ROA &, 085 & 2,854 &, 008 & H4 terdukung \\
SIZE &, 372 & 2,542 &, 026 & Terdukung \\
Adjusted ${ }^{2}$ & 0,554 & & & \\
F test & 0,002 & & & \\
\hline
\end{tabular}

Sumber: Data diolah, 2018

Berdasarkan tabel 3 maka prediksi nilai perusahaan dapat dirumuskan dalam persamaan regresi linier berganda sebagai berikut:

$$
\text { PBV = -1,667 + 0,071 DER + 0,299 ROA + 0,383 CSR + 0,085 CSR *ROA + 0,372 SIZE + e }
$$

Berdasarkan pada tabel 3 dapat dilihat bahwa besarnya koefisien determinasi yang menunjukkan nilai adjusted $\mathrm{R}$ Square sebesar 0,554 atau 55,4\%. Hal ini menunjukkan bahwa kontribusi variabel DER, ROA, CSR, Moderasi CSR*ROA, dan SIZE dapat menjelaskan nilai perusahaan sebesar 55,4\% sedangkan sisanya $44,6 \%$ dijelaskan oleh faktor lain diluar model yang digunakan.

Demikian juga nilai $\mathrm{F}$ hitung pada model penelitian sebesar 14,533 dengan nilai signifikansi 0,002. Nilai signifikansi berada dibawah 0,05 menunjukkan bahwa semua variabel independen sebesar 0,554 atau 55,4\%. Hal ini menunjukkan bahwa kontribusi variabel DER, ROA, CSR, Moderasi CSR*ROA, dan SIZE secara bersama-sama berpengaruh terhadap variabel nilai perusahaan. Sehingga secara keseluruhan model penelitian ini dinyatakan fit.

\section{Pengaruh ROA terhadap nilai perusahaan}

Hasil uji hipotesis membuktikan bahwa ROA berpengaruh positif signifikan terhadap nilai perusahaan.Kondisi ini menunjukkan investor menggunakan informasi profit dalam mempertimbangkan investasi. Dengan profit yang tinggi akan menarik minat investor karena cenderung diikuti dengan kebijakan pembagian deviden. Daya tarik jumlah laba ini menunjukkan perusahaan bernilai. Temuan ini mendukung teori sinyal bahwa informasi yang dirilis perusahaan memberikan sinyal bagi investor sehingga nilai perusahaan semakin baik. Temuan ini sejalan dengan penelitian Hartoyo (2013); Hadiyanto (2013); Deriyarso (2014); Putri (2015); Komariah (2015); dan I Ketut (2016) yang menyatakan ROA berpengaruh signifikan positif terhadap nilai perusahaan.

\section{Pengaruh leverage terhadap nilai perusahaan}

Hasil uji hipotesis membuktikan bahwa leverage yang diproksikan DER tidak berpengaruh terhadap nilai perusahaan. Kondisi ini menunjukkan DER pada penelitian ini memiliki nilai yang cukup rendah. Rendahnya DER menunjukkan perusahaan tidak mengandalkan pembiyaan operasional dengan hutang namun dengan menggunakan pembiayaan internal seperti laba ditahan. Sehingga pembiayaan dengan hutang tidak akan meningkatkan nilai perusahaan. Temuan ini sejalan dengan penelitian Sakti (2009) dan Bambang (2013) yang menyatakan leverage tidak berpengaruh terhadap nilai perusahaan. Namun sebaliknya Brigham dan Houston (2001) menyatakan peningkatan utang akan direspon oleh pasar. Untuk dampaknya terhadap laba faktor 
DER juga harus dibandingkan dengan penjualan yang lebih terpengaruh dengan faktor ekonomi makro yang luas.

\section{Pengaruh $C S R$ terhadap nilai perusahaan}

Hasil uji hipotesis membuktikan bahwa CSR berpengaruh terhadap nilai perusahaan. Kondisi ini menunjukkan bahwa perusahaan melakukan aktivitas CSR cukup tinggi yang ditunjukkan dengan transparansi pengungkapan CSR cukup memadai. Sehingga citra perusahaan menjadi semakin baik. Hal ini akan berdampak pada investor dalam mempertimbangkan pelaporan tahunan yang mengandung CSR dapat mempengaruhi goodwill atau reputasi perusahaan sehingga nilai perusahaan pun juga semakin tinggi. Temuan ini sejalan dengan Hartoyo (2013) CSR berpengaruh positif signifikan terhadap nilai perusahaan.

\section{Peran CSR dalam memoderasi ROA terhadap nilai perusahaan}

Hasil uji hipotesis membuktikan bahwa CSR mampu memperkuat pengaruh ROA terhadap nilai perusahaan. Kondisi demikian menunjukkan bahwa dengan profit yang tinggi dan didukung oleh aktifitas CSR yang tinggi ternyata mampu meningkatkan nilai perusahaan. Adanya profit yang tinggi perusahaan memiliki kewajiban terhadap masyarakat yaitu kepedulian perusahaan pada masyarakat dalam bentuk aktivitas CSR dan mengungkapkan aktivitas tersebut dalam pelaporan usaha, sehingga memiliki dampak positif terhadap kinerja keuangan dan nilai perusahaan. Banyak investor yang menggunakan strategi investasi secara eksplisit mempertimbangkan kriteria kinerja CSR disamping ukuran financial. Adanya pengungkapan CSR dapat menjadi pertimbangan investor dalam melakukan investasi. Temuan ini sejalan dengan Yuniasih dan Wirakusuma (2007); Putri (2015); dan I Ketut (2016) yang menyatakan CSR mampu memoderasi ROA terhadap nilai perusahaan.

\section{Pengaruh Size terhadap nilai perusahaan}

Demikian juga pada perusahaan dengan skala besar ternyata dipandang lebih mampu menciptakan nilai dibanding perusahaan dengan skala kecil. Semakin besar ukuran perusahaan, maka ada kecenderungan lebih banyak investor yang menaruh perhatian pada perusahaan tersebut. Hal ini disebabkan karena perusahaan yang besar cenderung memiliki kondisi yang lebih stabil dari tahun ke tahun utamanya dalam return saham kepada investor. Peningkatan permintaan saham perusahaan akan menjadi penyebab atas naiknya harga saham perusahaan di pasar modal yang berujung pada kenaikan nilai perusahaan (Zumrotun, 2013). Temuan ini sejalan dengan Eka (2010); Chen Li dan Chen Shun (2011); Martini dkk (2014); Maspupah (2014); I Gustu dan I Ketut (2016); dan Pramana (2016) bahwa size berpengaruh positif terhadap nilai perusahaan.

\section{Pengaruh ROA Terhadap Nilai Perusahaan}

Husnan (2000:11) menyatakan memaksimumkan nilai perusahaan tidak identik dengan memaksimumkan laba, bahkan memaksimumkan laba per lembar saham (EPS) pun juga tidak identik dengan memaksimumkan nilai perusahaan. Meskipun demikian, jika laba diartikan sebagai economic profit, maka memaksimumkan laba dalam jangka panjang akan konsisten dengan memaksimumkan nilai perusahaan. Salah satu upaya yang dapat dilakukan perusahaan adalah memaksimumkan profit. Profit yang tinggi akan memberikan indikasi prospek perusahaan yang baik sehingga dapat memicu investor dalam meningkatkan permintaan saham, selanjutnya nilai perusahaan juga meningkat (Soliha, 2002).

Dalam pecking order theory menjelaskan tentang hirarki pendanaan perusahaan lebih mengutamakan sumber pendanaan internal daripada eksternal serta mengutamakan pendanaan melalui hutang daripada emisi saham apabila pendanaan internal tidak mencukupi (Siregar, 2001). Myers (1984) dikutip dalam www.informasiku.com perusahaan dengan tingkat profitabilitas yang tinggi cenderung tingkat hutangnya rendah, dikarenakan dengan profitabilitas tinggi menunjukkan sumber dana internal berlimpah. Hal tersebut berarti semakin tinggi profitabilitas maka akan semakin rendah hutang dan saham sebagai sumber pendanaan dengan demikian akan meningkatkan nilai perusahaan. Hartoyo (2013); Hadiyanto (2013); Deriyarso (2014); Putri (2015); Komariyah (2015); I Ketut (2016); dan Pratama dan Wiksuana (2016) menemukan ROA memiliki pengaruh positif terhadap nilai perusahaan. Sehingga dapat dirumuskan hipotesis sebagai berikut. 
$\mathrm{H}_{1:}$ ROA berpengaruh positif terhadap nilai perusahaan

\section{Pengaruh Leverage Terhadap Nilap Perusahaan}

Mareta et al (2014) meyatakan bahwa leverage digambarkan untuk melihat sejauh mana asset perusahaan dibiayai oleh hutang dibandingkan dengan modal sendiri. Leverage besar menunjukkan risiko investasi yang besar pula. Perusahaan dengan leverage yang rendah memiliki risiko rendah pula. Leverage dapat tercermin dalam besaran Debt Equity Ratio (DER). Perusahaan dengan DER yang besar maka bagian laba yang akan dibagikan kepada pemegang saham akan kecil, sehingga dapat menurunkan harga saham. Semakin rendah DER maka nilai perusahaan akan semakin tinggi. Kondisi ini akan meningkatkan kepercayaan investor. Guspitasari (2013); Khumairoh dkk (2015); Khafa (2015); dan Linawaty dan Ekadjaja (2017) menemukan leverage berpengaruh negatif terhadap nilai perusahaan. Sehingga dapat dirumuskan hipotesis sebagai berikut. $\mathrm{H}_{2}$ : Leverage berpengaruh negatif terhadap nilai perusahaan

\section{Pengaruh CRS Terhadap Nilai Perusahaan}

Pengungkapan tanggungjawab sosial perusahaan merupakan proses pengkomunikasian dampak sosial dan lingkungan dari kegiatan ekonomi perusahaan terhadap masyarakat. Perusahaan yang memiliki kinerja lingkungan dan sosial yang baik akan direspon positif oleh investor melalui peningkatan harga saham. Apabila perusahaan memiliki kinerja lingkungan dan sosial yang buruk maka akan muncul keraguan dari investor sehingga direspon negatif melalui penurunan harga saham (Rustiarini, 2010). Penelitian Rustiarini (2010); Khafa (2015); dan Murnita dan Putra (2017) menunjukkan pengungkapan CSR berpengaruh positif pada nilai perusahaan. Sehingga dapat dirumuskan hipotesis sebagai berikut. $\mathrm{H}_{3}$ : CSR berpengaruh positif terhadap nilai perusahaan

\section{Pengaruh ROA Terhadap Nilai Perusahaan Dengan Moderasi CSR}

Jika laba semakin besar maka kinerja perusahaan semakin baik, sehingga memaksimumkan laba dalam jangka panjang akan konsisten dengan memaksimumkan nilai perusahaan. Ketika kondisi tersebut didukung oleh aktivitas social (CSR) yang tinggi maka akan meningkatkan nilai perusahaan. Keberlanjutan kinerja keuangan yang positif akan mudah dicapai dan diterima oleh pihak eksternal dengan melakukan pengungkapan CSR. Telah disebutkan dalam UU bahwa perusahaan yang aktivitasnya berhubungan dengan lingkungan alam wajib menerapkan CSR. Hal ini sejalan dengan stakeholder theory yang menjelaskan bahwa perusahaan tidak hanya memandang laba sebagai satu-satunya tujuan dari perusahaan, tetapi juga bentuk tanggung jawab kepada stakeholder, karena perusahaan mempunyai tanggung jawab yang lebih luas disbanding sekedar mencari laba untuk pemegang saham ( Luthfi, 2010). Peneltian Yuniasih dan Wirakusuma (2007); Oktavias (2015); dan I Ketut (2016) menemukan bahwa CSR mampu memoderasi ROA terhadap nilai perusahaan. Sehingga dapat dirumuskan hipotesis sebagai berikut. $\mathrm{H}_{4}$ : CSR memoderasi $R O A$ terhadap Nilai perusahaan

\section{Model Pemikiran Teoritis}

Berdasarkan penjelasan teoritis dan hasil empiric sebelumnya, maka dapat digambarkan model penelitian sebagai berikut.

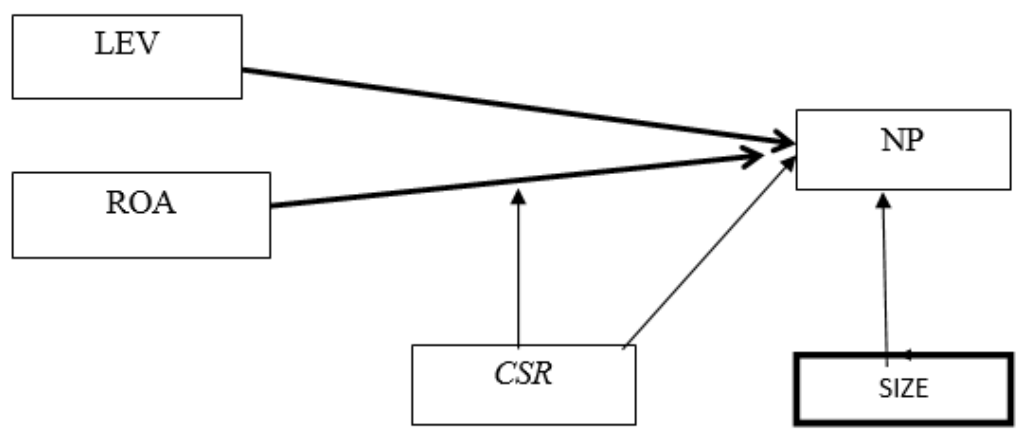

Gambar 1. Model Pemikiran Teoritis 
Keterangan:

$\begin{array}{ll}\text { ROA } & \text { Return On Asset } \\ \text { LEV } & =\text { Leverage } \\ \text { CSR } & =\text { Corporate Social Responsibility } \\ \text { NP } & =\text { Nilai perusahaan } \\ \text { SIZE } & =\text { Ukuran Perusahaan }\end{array}$

\section{KESIMPULAN}

Berdasarkan pengujian dan pembahasan maka dapat diambil kesimpulan sebagai berikut:

1. ROA berpengaruh positif signifikan terhadap nilai perusahaan.

2. DER tidak berpengaruh terhadap nilai perusahaan.

3. CSR berpengaruh positif signifikan terhadap nilai perusahaan.

4. CSR mampu memperkuat hubungan ROA terhadap nilai perusahaan.

5. SIZE berpengaruh positif signifikan terhadap nilai perusahaan.

6. Model penelitian ini mampu menjelaskan terbatas sebesar $55,4 \%$ variance nilai perusahaan.

Merupakan kebijakan manajemen dalam mengalokasikan dana CSR sebagai bentuk tanggung jawab pada masyarakat sehingga citra baik perusahaan akan dikenal menjadi lebih baik melalui kegiatan CSR. Namun investor tetap memandang bahwa kinerja laporan keuangan lebih diperhatikan jika ingin meningkatkan nilai perusahaan karena kinerja profitabilitas memiliki peran penting dalam meningkatkan nilai perusahaan.

\section{Saran}

Beberapa saran yang dapat direkomendasikan untuk penelitian selanjutnya adalah:

1. Perlu memperluas sub sektor dalam manufaktur sehingga dapat dilakukan analisis komparasi.

2. Perlu mengembangkan alternative proksi yang lain untuk mengukur nilai perusahaan, sehingga dapat dipilih model yang sesuai.

3. Perlu menambahkan variabel lain yang dapat mempengaruhi nilai perusahaan, seperti investment opportunity set, intellectual capital dan lain-lain.

\section{DAFTAR PUSTAKA}

Anggoro, Tri Susilo, 2009, "Pengaruh Inflasi, Kurs dan Suku bunga SBI terhadap Indeks Harga Saham Gabungan (IHSG) pada Bursa Efek Indonesia periode 2005-2009” Universitas sebelas Maret

Anindito, Dandi Teguh dan Eisha Lataruva, 2013, "Analisis Pengaruh Kualitas Pelayanan, Harga Dan Nilai Pelanggan Terhadap Kepuasan Pelanggan", Diponegoro Journal Of Management, Volume 3, Nomor 2, Tahun 2013, Hal. 1 - 7, Universitas Diponegoro (UNDIP), Semarang

Bambang,2009, "Pengaruh Kebijakan Hutang, Kebijakan Investasi, Dan Kebijakan Dividen Terhadap Nilai Perusahaan Manufaktur Terdaftar Di Bursa Efek Indonesia Tahun 20032007", Universitas Sebelas Maret Surakarta"

Chen, Li-Ju., dan Chen, Shun-Yu. (2011). The influence of profitability on firm value with capital structure as the mediator and firm size and industry as moderators. Investment Management and Financial Innovations journal, Volume 8, Issue 3, 2011.

Deriyarso, Irvan, 2014, "Pengaruh Profitabilitas Terhadap Nilai Perusahaan Dengan Corporate Social Responsibility Sebagai Variabel Moderating" Universitas Diponegoro Semarang

Guspitasari, Reni, 2013, "Pengaruh Kebijakan Dividen, Tingkat Inflasi, Tingkat Suku Bunga, Dan Leverage Terhadap Nilai Perusahaan Pada Perusahaan Manufaktur Yang Terdaftar Di Bursa Efek Indonesia (Bei) Periode 2009-2012"

Hartoyo, 2016," Analisis Pengaruh Profitabilitas, Pengungkapan Corporate Social Responsibility Dan Corporate Governance Terhadap Nilai Perusahaan" Universitas Muhamadiyah Surakarta

Hadianto Muhammad Lutfi, 2013, "Analisis Pengaruh Kinerja Keuangan Terhadap Nilai Perusahaan Dengan Pengungkapan CSR Dan GCG Sebagai Variabel Pemoderasi" Universitas Diponegoro Semarang 
Khafa. Lais. 2015. Pengaruh CSR, Ukuran Perusahaan, Leverage, Dan Keputusan Investasi Pada Kinerja Keuangan Perusahaan Dan Nilai Perusahaan (Studi Empiris pada Perusahaan Manufaktur yang terdaftar di Bursa Efek Indonesia tahun 2012-2013). Skripsi FEB Universitas Diponegoro.

Khumairoh, Nawang Kalbuana Dan Henny Mulyati. 2015. Pengaruh Leverage, Profitabilitas, Dan Ukuran Perusahaan Terhadap Nilai Perusahaan (Studi Empiris Pada Perusahaan Garment Dan Textile Yang Terdaftar Di Bursa Efek Indonesia Tahun 2011-2015). Syariah Paper Accounting FEB UMS.

Komariyah Siti, 2012, "Pengaruh Return On Asset Terhadap Nilai Perusahaan Dengan Corporate Social Responsibility Sebagai Variabel Moderasi Pada Perusahaan Yang Listing Di Jakarta Islamic Index (Jii) Periode 2011-2014”, Universitas Islam Negeri Walisongo Semarang

Linawaty dan Agustin Ekadjaja. 2017. Analisis Pengaruh Leverage Terhadap Nilai Perusahaan Dengan Kepemilikan Manajerial Dan Arus Kas Bebas Sebagai Variabel Pemoderasi. Jurnal Ekonomi/Volume XXII, No. 01. Maret 2017: 164-176

Murnita.Putu Elia Meilinda dan I Made Pande Dwiana Putra. 2017. Pengaruh Corporate Social Responsibilityterhadap NilaiPerusahaan dengan Profitabilitas dan Leverage sebagai Variabel Pemoderasi. E Jurnal Akuntansi Universitas Udayana. Vol.23. 2. Mei 2018. Pp:1470-1494

Ni Putu, 2014, "Pengaruh Faktor Eksternal Terhadap Nilai Perusahaan (PBV) dan Harga Saham Terhadap Perusahaan Manufaktur Di Bursa Efek Indonesia" Politeknik Negeri Bali

Nurminda. Aniela, Deannes Isynuwardhana, Annisa Nurbaiti. 2017. Pengaruh Profitabilitas, Leverage, Dan Ukuran Perusahaan Terhadap Nilai Perusahaan (Studi pada Perusahaan Manufaktur Sub Sektor Barang dan Konsumsi yang Terdaftar di Bursa Efek Indonesia Periode 2012-2015). e-Proceeding of Management : Vol.4, No.1 April.

Ogolmagai. Natalia. 2013. Leverage Pengaruhnya Terhadap Nilai Perusahaan Pada Industri Manufaktur Yang Go Public Di Indonesia. Jurnal Riset Ekonomi, Manajemen, Bisnis dan Akuntansi. 2013.Vol.1 No.3

Pramana I Gusti, Mustanda, 2016 “ Pengaruh Profitabilitas Dan Size Terhadap Nilai Perusahaan Dengan CSR Sebagai Variabel Pemoderasi” E-Jurnal Manajemen Unud, Vol. 5, No.1, 2016: $561-594,2016$

Pratama. I. Gusti Bagus Angga dan I. Gusti Bagus Wiksuana. 2016. Pengaruh Ukuran Perusahaan dan Leverage terhadap Nilai Perusahaan dengan Profitabilitas sebagai Variabel Mediasi. EJurnal Manajemen Universitas Udayana. 2016. Vol. 5, No. 2, 2016: 1338-1367.

Prihantini, Ratna, 2009, "Analisis Pengaruh Inflasi, Nilai Tukar, ROA, DER Dan CR Terhadap Return Saham" Universitas Diponegoro

Pristianingrum. Nurfina. 2017. Pengaruh Ukuran, Profitabilitas, Dan Pengungkapan CSR Terhadap Nilai Perusahaan Manufaktur Yang Terdaftar Di Bursa Efek Indonesia. Prosiding Seminar Nasional dan Call For Paper Ekonomi dan Bisnis (SNAPER-EBIS 2017) - Jember, 27-28 Oktober 2017 (hal 353-364). ISBN : 978-602-5617-01-0

Rahayu, Sri, 2010,“ Pengaruh Kinerja Keuangan Terhadap Nilai Perusahaan Dengan Pengungkapan Corporate Social Responsibility dan Good Corporate Governance Sebagai Variabel Pemoderasi" Universitas Diponegoro

Ramadhani. Ridho, Akhmadi dan M. Kuswantoro. 2018. Pengaruh Leverage Dan Profitabilitas Terhadap Nilai Perusahaan Dengan Kebijakan Dividen Sebagai Variabel Intervening (Studi Kasus Pada Perusahaan Manufaktur Yang Terdaftar Di Bursa Efek Indonesia Periode 20122016). Jurnal Riset Bisnis dan Manajemen Tirtayasa (JRBMT), Vol. 2 (1).

Rustiarini, Ni Wayan.2009.”Pengaruh Corporate Governance pada Hubungan Corporate Social Responsibility dan Nilai Perusahaan" Simposium Nasional Akuntansi XII. Purwokerto 2010

Sambora Mareta Nurjin, Siti Ragil Handayani,dan Sri Mangesti Rahayu, 2014, "Pengaruh Leverage Dan Profitabilitas Terhadap Nilai Perusahaan” Jurnal Administrasi Bisnis (JAB)| Vol. 8 No. 1 tahun 2014 Universitas Brawijaya Malang

Wahyu, Deni, 2009, "Analisis Pengaruh Suku Bunga, Volume Perdagangan Dan Kurs Terhadap Return Saham Sektor Properti Yang Listed Di Bei” Universitas Diponegoro 
Wahyu, Dwi, 2010, “Analisis Pengaruh Faktor Fundamental Ekonomi Makro Dan Harga Minyak Terhadap Saham Lq45 Dalam Jangka Pendek Dan Jangka Panjang” Journal of Indonesian Applied Economics Vol. 4 No. 1 Mei 2010, 11-25, Universitas Brawijaya

Wahyudi, Asto 2012, "Pengaruh Profitabilitas, Likuiditas, Dan Leverage Terhadap Nilai Perusahaan" Universitas Muhammadiyah Surakarta

Winda, Ade, 2015, "Pengaruh Profitabilitas, Keputusan Investasi, Keputusan Pendanaan, Dan Kebijakan Dividen Terhadap Nilai Perusahaan Pada Perusahaan Manufaktur Yang Terdaftar Di Bursa Efek Indonesia"

Witha, Ni Made 2012, "Pengaruh Faktor Ekonomi Makro Dan Kinerja Keuangan Terhadap Nilai Perusahaan Manufaktur Di Bursa Efek Indonesia" Universitas Udayana 